\title{
Tingkat kepuasan terhadap pembersih gigitiruan pada pengguna gigitiruan di Rumah Sakit Gigi Mulut Fakultas Kedokteran Gigi Universitas Hasanuddin Satisfaction level about denture cleanser of denture wearers on the Dental Hospital Faculty of Dentistry Hasanuddin University
}

\author{
${ }^{1}$ Reisintiya, ${ }^{2}$ Eri H. Jubhari \\ ${ }^{1}$ Mahasiswa tahap profesi \\ ${ }^{2}$ Bagian Prostodonsia \\ Fakultas Kedokteran Gigi Universitas Hasanuddin \\ Makassar, Indonesia
}

\begin{abstract}
Patient dissatisfaction occurs in both developing and developed countries. Patient satisfaction is a very subjective thing; it is difficult to measure, changeable and there are many factors influencing person's level of satisfaction. Betel leaf (Piper betle) has many benefits to health. Betel leaf is a natural ingredient that is known to contain phenols and volatile oil which gives the most distinctive smell in the betel leaf. Solution of betel leaf can also be used as a mouthwash and denture cleansers. In addition, there are several kinds of commercially available cleanser, such as alkaline peroxide. This study was aimed to know the level of denture users' satisfaction in Dental Hospital, Faculty of Dentistry, Hasanuddin University against denture cleanser. By using an observational analytic method, sample of this study were all removable denture users inserted in April to May 2013. Polident and betel leaf extract of 20\% were used as cleansers. Data were collected by questionnaires and processed by chi-square test using SPSS v.21.0. The level satisfied of patient using alkaline peroxide was 100; compared with betel leaf extract of $20 \%$ was dissatisfied ( $p=$ 0.000). It was concluded that alkaline peroxide denture cleanser gives a different sense of satisfaction significantly compared with the betel leaf extract.
\end{abstract}

Keywords: level of satisfaction, betel leaf extract, alkaline peroxide

\begin{abstract}
ABSTRAK
Masalah ketidakpuasan pasien terjadi di negara berkembang maupun maju. Kepuasan pasien merupakan hal yang paling sangat subjektif, sulit diukur, berubah-ubah, serta terdapat banyak faktor yang mempengaruhinya. Daun sirih mempunyai banyak manfaat untuk kesehatan. Daun sirih merupakan bahan alam yang memiliki kandungan fenol dan minyak atsiri, yang merupakan komponen paling banyak yang memberi bau khas. Larutan daun sirih juga dapat digunakan sebagai obat kumur dan pembersih gigitiruan. Selain itu telah terdapat beberapa macam bahan pembersih yang tersedia di pasaran, misalnya peroksida alkali (Polident). Penelitian dimaksudkan untuk mengetahui tingkat kepuasan pasien pengguna gigitiruan di RSGMP Fakultas Kedokteran Gigi Universitas Hasanuddin terhadap bahan pembersih gigitiruan. Dengan menggunakan metode observasional analitik, ditentukan sampel adalah semua pasien pemakai baru gigitiruan lepasan pada bulan April dan Mei 2013. Bahan pembersih yang digunakan yaitu peroksida alkali dan ekstrak 20\% daun sirih. Data dikumpulkan dengan kuesioner dan diolah dengan uji chi-square menggunakan SPSS 21,0. Diperoleh hasil bahwa tingkat kepuasan pasien pengguna peroksida alkali adalah 100\%; dibandingkan dengan ekstrak daun sirih 100\% tidak puas $(\mathrm{p}=0,000)$. Disimpulkan bahwa bahan pembersih gigitiruan peroksida alkali menimbulkan rasa puas yang berbeda bermakna dibandingkan dengan bahan ekstrak daun sirih.
\end{abstract}

Kata kunci: tingkat kepuasan, ekstrak daun sirih, peroksida alkali

Koresponden: Reisintiya, E-mail: tyadzeqret@ymail.com

\section{PENDAHULUAN}

Tingkat kepuasan pasien merupakan salah satu hal penting dalam mengevaluasi mutu layanan suatu rumah sakit. Kepuasan didefinisikan sebagai tingkat perasaan seseorang setelah membandingkan kinerja atau hasil yang dirasakan dengan harapannya. ${ }^{1}$ Dari aspek penyelenggaraan layanan kesehatan gigi, salah satu faktor pendukung klasik masalah kesehatan gigi dan mulut adalah layanan medis teknis kesehatan gigi mulut yang tidak optimal. ${ }^{2}$ Penilaian keberhasilan perawatan dengan gigitiruan lepasan dapat dilakukan dengan menggunakan indikator rasa nyaman dalam mulut, pulihnya fungsi pengunyahan, estetika dan bicara. ${ }^{3}$ Kebersihan rongga mulut pemakai gigitiruan harus tetap diperhatikan, karena kebersihan gigitiruan akan mendukung kesehatan rongga mulut secara menyeluruh. Para pemakai gigitiruan lepasan harus telaten membersihkan gigitiruannya agar sisa-sisa makanan tidak menempel pada gigitiruan. Gigitiruan yang tidak bersih menyebabkan plak yang menempel pada basis gigitiruan semakin banyak. Selain itu, permukaan yang kasar pada basis gigitiruan yang menghadap mukosa merupakan tempat melekatnya mikroba plak. Untukitu telah diusahakan bermacam- 
macam cara dan bahan untuk membersihkan gigitiruan. $^{4}$

Gigitiruan adalah piranti yang dibuat untuk menggantikan gigi yang hilang dan jaringan lunak di sekitarnya.Pirantijenis ini dibuat untuk memperbaiki penampilan, penguncapan serta perbaikan fungsi pengunyahan. Gigitiruan lepasan adalah gigitiruan yang menggantikan satu atau lebih gigidan jaringan sekitarnya, serta didukung oleh gigi dan jaringan di bawahnya serta dapat dikeluarmasukkan ke dalam mulut oleh pemakainya. Jika tidak menggunakan gigitiruan, dapat terjadi migrasi dan rotasi gigi, erupsi berlebih, penurunan efisiensi kunyah, gangguan pada sendi temporomandibula, beban berlebihan pada jaringan lunak, kelainan berbicara, memburuknya penampilan, terganggunya kebersihan mulut dan efek terhadap jaringan mulut. ${ }^{5}$

Pembersih gigitiruan adalah sebuah bahan yang digunakan untuk membersihkan gigitiruan. Adapun jenis pembersih gigitiruan kimia dapat berupa krim, bubuk cair, atau tablet. Selainitu ada juga pembersih gigitiruan secara mekanik yang dapat dilakukan dengan menyikat gigitiruan menggunakan sikat dan teknik ultrasonik. ${ }^{6}$ Peroksida alkali adalah metode yang aman dan efektif membersihkan gigitiruan dan sterilisasi, khususnya di kalangan pasien yang berusia lanjut ${ }^{7}$. Daun sirih merupakan bagian tanaman obat tradisional yang erat kaitannya dengan kesehatan gigi dan mulut.

Penggunaan tumbuhan sirih sebagai bahan obat mempunyai dasar kuat karena adanya kandungan minyak atsiri yang merupakan komponen fenol alami sehingga berfungsi sebagai antiseptik yang kuat. Atsiri merupakan minyak yang mudah menguap dan mengandung aroma wangi yang khas. Minyak atsiri dalam daun sirih mengandung 30\% fenol; sedangkan kandungan lain dari minyak atsiri adalah kavikol yang merupakan komponen yang paling banyak yang memberi bau khas pada daun sirih. Persenyawaan fenol memiliki aktivitas antibakteri dan minyak atsiri sebagai antijamur dan antioksidan. ${ }^{8}$

Penelitian ini dimaksudkan untuk mengetahui tingkat kepuasan pasien terhadap bahan pembersih gigitiruan yang digunakan oleh pemakai gigitiruan lepasan di Rumah Sakit Gigi dan Mulut Fakultas Kedokteran Gigi Universitas Hasanuddin, antara peroksida alkali dengan ekstrak $20 \%$ daun sirih.

\section{BAHAN DAN METODE}

Penelitian didesain observasional analitik untuk mengetahui tingkat kepuasan pasien pengguna bahan pembersih gigitiruan, dengan menggunakan skala Likert. Penelitian ini dilaksanakan di RSGM FKG Unhas pada bulan April hingga Mei tahun 2013.
Pengambilan sampel menggunakan metode tottally sampling hingga diperoleh 26 orang pasien. Dengan kriteria inklusi yaitu, pasien gigitiruan lepasan yang melakukan insersi saat penelitian, mengisi lembar persetujuan untuk menjadi responden, dan kuesioner dengan lengkap.

Penelitian menggunakan instrument kuesioner yang telah diadaptasi. Kuesioner, antara lain berisi pertama, tentang karakteristik sampel yang meliputi umur, jenis kelamin, tingkat pendidikan, serta status perkawinan; kedua tentang gigitiruan yang digunakan meliputi waktu,pemahaman dan ketanggapan;ketiga tentang kepuasan pasien yang menggunakan bahan pembersih gigitiruan, meliputi kesegaran, kebersihan serta kenyamanan. Pilihan jawaban deskripsi yang digunakan ialah sangat puas, puas, ragu-ragu, tidak puas, serta sangat tidak puas yang dilambangkan dengan skala 1 sampai 5 .

Nilai yang diperoleh dijumlahkan sehingga dapat dikategorikan menjadi sangat puas (skor total 3240), kategori puas (skor total 24-31), kategori raguragu (16-23), kategori tidak puas (8-15), dan kategori sangat tidak puas (skor total $\leq 8$ ).

\section{HASIL}

Dari 26 responden penderita yang melakukan insersi gigitiruan lepasan, didominasi oleh pasien perempuan, pada kelompok usia $>30$ tahun; sebagian besar menyelesaikan tingkat pendidikan menengah atas, serta jenis pekerjaan yang paling banyak pada responden adalahibu rumah tangga. Sejumlah 57,7\% responden memperoleh penjelasan mengenai cara membersihkan gigitiruan, akan tetapi kurang jelas memahami cara membersihkan gigitiruan. Sebanyak $65,4 \%$ responden yang menjalankan instruksi cara membersihkan gigitiruan tetapi kurang memahami instruksi. Berdasarkan cara pembersihan gigitiruan, $69,2 \%$ sampel menyikat dan merendam gigitiruannya, tetapi $65,4 \%$ sampel tidak membersihkan gigitiruan secara teratur. Semua pasien pengguna gigitiruan tak pernah mengganti bahan pembersih gigitiruannya yaitu selalu menggunakan air untuk membersihkan gigitiruan. Sebanyak 50\% responden mengalami masalah dengan pembersih gigitiruannyadan $42,3 \%$ sampel mengatakan puas dengan bahan pembersih gigitiruan yang digunakan.

Data hasil penelitian mengenai tingkat kepuasan pasien pengguna gigitiruan terhadap bahan-bahan pembersih gigitiruan menunjukkan bahwa dari 26 responden, sebanyak 13 orang (50\%) menyatakan puas menggunakan bahan pembersih jenis peroksida alkali dan sebanyak 13 orang (50\%) menyatakan tidak puas menggunakan bahan pembersih ekstrak $20 \%$ daun sirih. 
Tabel 1 Jawaban responden tentang kepuasan menggunakan bahan pembersih gigitiruan

\begin{tabular}{|c|c|c|c|c|c|c|c|}
\hline $\begin{array}{l}\mathrm{N} \\
\mathrm{O}\end{array}$ & Pertanyaan & $\mathrm{n}$ & $\begin{array}{l}\text { SP } \\
(\%)\end{array}$ & $\begin{array}{l}\mathrm{P} \\
(\%)\end{array}$ & $\begin{array}{l}\mathrm{RR} \\
(\%)\end{array}$ & $\begin{array}{l}\mathrm{TP} \\
(\%)\end{array}$ & $\begin{array}{l}\text { STP } \\
(\%)\end{array}$ \\
\hline 1 & $\begin{array}{l}\text { Apakah puas menggunakan pembersih gigitiruan demi kebersihan } \\
\text { mulut? }\end{array}$ & & & & & & \\
\hline & A. Peroksida alkali & 13 & 7,7 & 76,9 & 15,4 & 0 & 0 \\
\hline & B. Daun sirih & 13 & 0 & 0 & 0 & 69,2 & 30,8 \\
\hline 2 & $\begin{array}{l}\text { Apakah puas terhadap penampilan sejak menggunakan pembersihan } \\
\text { gigitiruan? }\end{array}$ & & & & & & \\
\hline & A. Peroksida alkali & 13 & 15,4 & 84,6 & 0 & 0 & 0 \\
\hline & B. Daun sirih & 13 & 0 & 0 & 0 & 100 & 0 \\
\hline 3 & $\begin{array}{l}\text { Apakah merasa puas dengan tingkat kesegaran gigitiruan yang telah } \\
\text { dibersihkan terlebih dahulu? }\end{array}$ & & & & & & \\
\hline & A. Peroksida alkali & 13 & 23,1 & 69,2 & 7,7 & 0 & 0 \\
\hline & B. Daun sirih & 13 & 0 & 0 & 0 & 69,2 & 30,8 \\
\hline 4 & $\begin{array}{l}\text { Apakah merasa puas dengan tingkat kebersihan gigitiruan yang telah } \\
\text { dibersihkan terlebih dahulu? }\end{array}$ & & & & & & \\
\hline & A. Peroksida alkali & 13 & 30,8 & 61,5 & 7,7 & 0 & 0 \\
\hline & B. Daun sirih & 13 & 0 & 0 & 0 & 61,5 & 38,5 \\
\hline 5 & $\begin{array}{l}\text { Apakah merasa puas dengan tingkat kenyamanan gigitiruan yang telah } \\
\text { dibersihkan terlebih dahulu? }\end{array}$ & & & & & & \\
\hline & A. Peroksida alkali & 13 & 53,8 & 46,2 & 0 & 0 & 0 \\
\hline & B. Daun sirih & 13 & 0 & 0 & 0 & 38,5 & 53,8 \\
\hline 6 & $\begin{array}{l}\text { Apakah merasa puas menggunakan gigitiruan yang telah dibersihkan } \\
\text { terlebih dahulu sebelum makan dan minum? }\end{array}$ & & & & & & \\
\hline & A. Peroksida alkali & 13 & 38,5 & 61,5 & 0 & 0 & 0 \\
\hline & B. Daun sirih & 13 & 0 & 0 & 7,7 & 61,5 & 30,8 \\
\hline 7 & $\begin{array}{l}\text { Apakah puas menggunakan gigitiruan yang telah dibersihkan pada saat } \\
\text { anda berbicara? }\end{array}$ & & & & & & \\
\hline & A. Peroksida alkali & 13 & 30,8 & 69,2 & 0 & 0 & 0 \\
\hline & B. Daun sirih & 13 & 0 & 0 & 7,7 & 76,9 & 15,4 \\
\hline 8 & $\begin{array}{l}\text { Apakah puas menggunakan gigitiruan yang telah dibersihkan terlebih } \\
\text { dahulu pada saat berpergian? }\end{array}$ & & & & & & \\
\hline & A. Peroksida alkali & 13 & 46,2 & 46,2 & 7,7 & 0 & 0 \\
\hline & B. Daun sirih & 13 & 0 & 0 & 0 & 53,8 & 46,2 \\
\hline
\end{tabular}

SP: sangat puas; P: puas; RR: ragu-ragu; TP: tidak puas; STP: sangat tidak puas

Tabel 2 Pengujian statistik dengan chi-square

\begin{tabular}{lccccc}
\hline \multicolumn{6}{c}{ Uji chi-square } \\
\hline & Value & Df & $\begin{array}{c}\text { Asymp. Sig. } \\
(2 \text {-sided })\end{array}$ & $\begin{array}{c}\text { Exact Sig. } \\
(2 \text {-sided })\end{array}$ & $\begin{array}{c}\text { Exact Sig. } \\
(1 \text {-sided })\end{array}$ \\
\hline $\begin{array}{l}\text { Pearson Chi-Square } \\
\text { Continuity Correction }\end{array}$ & 26,000 & 1 & 0,000 & & \\
$\begin{array}{l}\text { Likelihood Ratio } \\
\text { Fisher's Exact Test }\end{array}$ & 22,154 & 1 & 0,000 & & \\
$\begin{array}{l}\text { Linear-by-Linear Association } \\
\text { Nof Valid Cases }\end{array}$ & 36,044 & 1 & 0,000 & & \\
\hline
\end{tabular}

Sebanyak $53,2 \%$ sampel tidak pernahmengganti bahan pembersih gigitiruannya (air) karena air lebih mudah penggunaannya pada saat membersihkan gigitiruan. Masalah yang dialami dengan bahan pembersih gigitiruan jenis ekstrak $20 \%$ daun sirih yaitu, 34,6\% sampel mengatakan kurang bersih dan 26,9\% sampel mengatakan baunya tidak enak.

Padahasil penelitian ini terbuktibahwa terdapat perbedaan yang signifikan antara kepuasan pasien menggunakan bahan pembersih gigitiruan sediaan peroksida alkali dan pembersih gigitiruan alami, yaitu ekstrak $20 \%$ daun sirih dengan uji chi-square $(p=0,0000 ; p<0,05)$. Hal ini menunjukkan kepuasan pasien dipengaruhi oleh komposisibahan pembersih gigitiruan,kesegaran, kenyamanan, harga terjangkau, mudah diperoleh dan mudah penggunaannya.

\section{PEMBAHASAN}

Jumlah wanita yang menggunakan gigitiruan lebih banyak dibandingkan laki-laki. Sejalan dengan 
hasil penelitian Raphael dkk, ${ }^{9}$ yang menyatakan wanita lebih memperhatikan kesehatan dan estetik. Munculnya persamaan hasil penelitian ini dengan penelitian sebelumnya mungkin karena di RSGMP FKG UNHAS pada bulan April hingga Mei, lebih banyak pasien wanita yang menjalani perawatan dan melakukan insersi gigitiruan lepasan.

Dari penelitian inijuga diketahui adanyatingkat pendidikan yang bervariasi yaitu hanya sedikit dari sampel tidak menyelesaikan pendidikan dasarnya, dan sebanyak 42,3\% sampel yang menyelesaikan pendidikan menengahnya.Meningkatnya pendidikan ini menyebabkan meningkatnya kesadaran terhadap kebersihan gigi dan mulut yang dapat menyebabkan kehilangan gigi. Hal ini sesuai dengan hasil studi yang dilakukan Esan dkk, ${ }^{10}$ bahwa meningkatnya tingkat pendidikan seseorang akan meningkatkan kesadaran terhadap kesehatan gigi dan mulutnya, makin meningkat kesadaran penggunaan fasilitas kesehatan gigi dan mulut, serta menjaga kesehatan gigi dan mulut sebagaimana mestinya.

Terlihat bahwa $57,7 \%$ responden mendapatkan penjelasan mengenai cara membersihkan gigitiruan tapi kurang memahami cara membersihkan gigitiruan, $65,4 \%$ responden yang menjalankan instruksi cara membersihkan gigitiruan tetapi kurang memahami instruksi tersebut dan tidak membersihkan gigitiruan secara teratur. Hal ini selaras dengan penelitian Soelarso dkk, ${ }^{2}$ yang mengungkapkan bahwa salah satu pendukung klasik masalah kesehatan gigi dan mulut adalah layanan medis teknis kesehatan gigi dan mulut yang tidak optimal, proses komunikasi yang tidakoptimal membuat pasien tidak memahami maksud dan tujuan penjelasan yang disampaikan kepada mereka. Menurut Raphael, dkk ${ }^{9}$, dikatakan bahwa aspek pemeliharan dan kebersihan gigitiruan menunjukkan hasil yang sangat mencemaskan; salah satu disebabkan karena kurangnya instruksi yang diberikan kepada pasien pengguna gigitiruan dan menurunnya kemampuan motorik pasien karena faktor usia. Semua pasien menggunakan air untuk membersihkan gigitiruan dan teknik yang digunakan $69,2 \%$ menyikat dan merendam gigitiruan. Hasil pembersihan tidaklah efektif seperti pendapat oleh Lee, $\mathrm{dkk}^{11}$ bahwa menyikat gigitiruan tidak efektif menghilangkan plak pada basis gigitiruan melainkan hanya menghilangkan partikel besar dari lapisan basis gigitiruan sehingga mempengaruhi permukaan gigitiruan menjadi kasar serta dapat meningkatkan pertumbuhan mikroorganisma pada plat gigitiruan.

Masalah dialami akibat menggunakan bahan pembersih gigitiruan jenis ekstrak daun sirih adalah kutangnya tingkat kesegaran, kebersihan, serta kenyamanan, bau yang tidak enak dan mengubah warna basist gigitiruan. Menurut Hermawan dkk, ${ }^{12}$ dikatakan bahwa dengan konsentrasi 2,5\% ekstrak daun sirih sangat berpengaruhterhadap pertumbuhan bakteri. Hal ini kontradiktif dengan masalah yang terjadi pada pengguna ekstrak $20 \%$ daun sirih yang mengatakan kurang bersih. Masalah ini terjadi akibat karena endapan dan larutan pada ekstrak 20\% daun sirih tidak dipisahkan sehingga endapan menempel pada plat gigitiruan.

Berdasarkan hasil penelitian dan pembahasan, disimpulkan bahwa pengguna gigitiruan lebih puas menggunakan peroksidaalkali dibandingkan dengan ekstrak 20\% daun sirih. Selainitu pengguna gigitiruan harus memiliki perhatian terhadap bahan pembersih dan metode yang digunakan untuk membersihkan gigitiruan. Beberapa masalah yang dihadapi oleh pengguna gigitiruan adalah mereka mendapatkan penjelasan mengenai cara membersihkan gigitiruan tetapi tidak memahami instruksi yang didapatkan. Kepuasan pengguna gigitiruan akan bahan pembersih yang digunakannya sangat bervariasi. Hal tersebut dipengaruhioleh kondisi individu tersebut.Kepuasan terhadap bahan pembersih gigitiruan dipengaruhi oleh tingkat kebersihan, tingkat kesegaran, serta tingkat kenyamanan dari bahan pembersih.

Berdasarkan hasil penelitian tersebut, disarankan untuk melakukan penyuluhan cara membersihkan gigitiruan, yang diharapkan dapat memberi informasi kepada masyarakat yang menggunakan gigitiruan tentang pentingnya menjaga kebersihan gigitiruan demi kesehatan mulut agar tidak terjadi stomatitis dan penyakit lain yang diakibatkan penggunaannya.

\section{DAFTAR PUSTAKA}

1. Anas ASA, Abdullah AZ. Studi mutu pelayanan berdasarkan kepuasan pasien di klinik gigi dan mukut RSUP Dr.Wahidin Sudirohusodo makasassar. J Dentofasial 2008;7:100.

2. Soelarso H, Soebakti RH, Mufid A. Peran komunikasi interpersonal dalam pelayanan kesehatan gigi. Dent $\mathbf{J}$ 2005; 38:124-8.

3. Zlataric KD. Treatment outcomes with removable partial denture a comparison between patient and prosthodontist asessments. J Prosthodont 2001; 14:423-4.

4. Dwiatmoko S, Kristiana D. Pengaruh komunikasi kesehatan secara lisan dan tulisan terhadap pengetahuan sikap dan kebersihan gigitiruan para pemakai gigitiruan lepasan. J Dentika 2011; 16:14.

5. Gunadi HA, Margo A, Burhan LK, Suryatenggara F,Setiabudi I. Ilmu geligi tiruan sebagian lepasan jilid 1. Jakarta: Hipokrates;1991. p.12 
6. American Dental Association. Denture cleanser [internet] 2011. Available from http://www.ada.org/1317.aspx. Diakses 11 desember 2012.

7. Zarb GA, Bolender CL, Eckert S, Jacob R, Fenton A, Stern RM. Prosthodontic treatment for edentolous patient $12^{\text {th }}$ ed. St.Louis: Mosby; 2003. p.202-3.

8. Rahmah N, Rahman A. Uji fungistatik ekstrak daun sirih (piper betle L.) terhadap candida albicans. J Bioscientiae 2010;7(2):17-8.

9. Raphael FS, Andrea SS, Maria PD, Rumola RR, Ana PZ, Helena DF, et.al. Association between denture hygine and oral health-related quality of life in edentolous patient. Revista De Odontolgia Da Unesp.[online] 2013 [cited 2013 june 17]. January 2012;41(1):48-53. Available from:URL: http://www.revodontolunesp.com.br/ files/v41n1/v41n1a09.pdf.

10. Esan TA, Olusile AO, Akeredolu PA, Esan AO. Socio-demographic factors and edentulism: the Nigerian experience. BMC Oral Healt.[online] 2013 [cited 2013 June 7]. December 2004; 4:5. Available from: URL: http://www.biomedcentral.com/1472-6831/4/3

11. Lee HE, Li CY, Chang HW, Yang YH, Wu JH. Effect of different denture cleaning methods to remove candida albicans from acrylic resin denture based material. J Dent Sci [online] 2013 [cited 2013 june 8]. July 2011; 216:220. Available from: URL: http://www.e-jds.com/article/S1991-7902\%2811\%2900080-8/abstract

12. Hermawan A, Eliyani H, Tyasningsih W. Pengaruh ekstrak daun sirih (piper betle 1.) terhadap pertumbuhan staphylococcus aureus dan escherichia coli dengan metode difusi disk. J Unair [online] 2013 [cited 2013 july16]. Available from: URL: http://journal.unair.ac.id/filerPDF/15.\%20Daun\%20Sirih.pdf. 